\title{
ANALISIS PENCAPAIAN TUJUAN BANK SYARIAH SESUAI UU NO 21 TAHUN 2008
}

\author{
Yayat Rahmat Hidayat, Maman Surahman \\ Universitas Islam Bandung Jalan Rangagading NO 08 Bandung Indonesia \\ yayatrahmat92@gmail.com \\ mamansurahman@unisba.ac.id
}

\begin{abstract}
Abstrak
Penelitian ini dilakukan untuk mengetahui pencapaian tujuan bank syariah yang terkandung dalam UU No 21 Tahun 2008 tentang Perbankan Syariah. Pada UU tersebut disebutkan bahwa bank syariah memiliki tujuan untuk meningkatkan pemerataan kesejahteraan rakyat. Oleh karena itu usaha-usaha yang dilakukan bank syariah, terutama melalui pembiayaan yang disalurkannya haruslah dapat meningkatkan tingkat pemerataan kesejahteraan rakyat atau mengurangi kesenjangan pendapatan rakyat yang diwakili dengan rasio gini. Dengan demikian penyaluran pembiayaan bank syariah harus memiliki pengaruh yang negative terhadap rasio gini. Hasil penelitian ini menunjukkan bahwa penyaluran pembiayaan bank syariah berpengaruh signifikan secara positif sebesar $67,4247 \%$. Sisanya sebesar $32,5753 \%$ dipengaruhi oleh faktor lain di luar penelitian. Persamaan yang didapat dari hasil pengujian di atas yaitu $\mathrm{Y}=3.10 \mathrm{E}-07+0.366204 \mathrm{X}$. Dari persamaan di atas bisa dilihat bahwa penyaluran pembiayaan bank syariah berpengaruh positif terhadap rasio gini. Setiap penambahan 1 satuan penyaluran pembiayaan bank syariah akan menambah 0.366204 satuan tingkat kesenjangan pendapatan rakyat.
\end{abstract}

Kata kunci: pembiayaan bank syariah, pemerataan kesejahteraan rakyat, rasio gini

\begin{abstract}
This study was conducted to determine the achievement of the objectives of Islamic banks is contained in UU No. 21 of 2008 concerning Islamic Banking. There are the Islamic banks have a goal to improve the distribution of welfare. Therefore, efforts were made Islamic banks, especially through the distributed financing must improve the level of people's welfare distribution or reduce income inequalities of the people represented by the gini ratio. Then the Islamic bank financing should have a negative influence on gini ratio. The results of this study showed that the distribution of Islamic bank financing have a significant positive influence of $67.4247 \%$. The remaining amount of $32.5753 \%$ influenced by other factors outside the research. The equation obtained from the above test results is $Y=3.10 E-07+$ 0.366204 X. From the equation above can be seen that the distribution of Islamic bank financing have a positive influence on the Gini ratio. Each additional 1 unit of Islamic bank financing will add to 0.366204 units of people's income gap.
\end{abstract}

Keywords: Islamic bank financing, distribution of welfare, gini ratio.

Received: 2016-09-16 | Reviced: 2017-01-30| Accepted: 2017-01-31

Indexed : DOAJ, Garuda, Crossref, Google Scholar | DOI: https://doi.org/10.29313/amwaluna.v1i1.1996 


\section{PENDAHULUAN}

\section{A. Latar Belakang Masalah}

Bank adalah badan usaha yang menghimpun dana dari masyarakat dalam bentuk simpanan dan menyalurkannya kepada masyarakat dalam bentuk kredit dan atau bentuk-bentuk lainnya dalam rangka meningkatkan taraf hidup rakyat banyak. Sedangkan Bank Syariah adalah Bank Umum sebagaimana dimaksud dalam UU No. 7 Tahun 1992 tentang perbankan sebagaimana telah diubah dengan UU No. 10 Tahun 1998 dan UU No 21 Tahun 2008, yang melakukan kegiatan usaha berdasarkan syariah.

\section{Dalam UU No 21 Tahun} 2008 Pasal 3 disebutkan bahwa Perbankan Syariah bertujuan menunjang pelaksanaan pembangunan nasional dalam rangka meningkatkan keadilan, kebersamaan, dan pemerataan kesejahteraan rakyat. Dari tujuan bank syariah yang tercantum dalam UU No 21 Tahun 2008 Pasal 3 diatas kita dapat mengetahui bahwa tujuan perbankan syariah adalah untuk menunjang pembangunan nasional dengan indikator ketercapaiannya yaitu keadilan, kebersamaan, dan pemerataan kesejahteraan rakyat. Untuk melihat pemerataan kesejahteraan rakyat kita bisa melihat dari angka rasio gini yang dikeluarkan oleh BPS. (Saleh, 2002) (Radhi, 2008) (Rustariyuni, 2014). Rasio gini merupakan alat untuk mengukur derajat ketidakmerataan distribusi penduduk. Ini didasarkan pada kurva Lorenz, yaitu sebuah kurva pengeluaran kumulatif yang membandingkan distribusi dari suatu variable tertentu (misalkan pendapatan) dengan distribusi uniform (seragam) yang mewakili persentase kumulatif penduduk. Dengan demikian rasio gini dapat digunakan untuk mengukur tingkat ketimpangan pendapatan secara menyeluruh. (Arifianto, 2013) (Eka, Amar, \& Aimon, 2015)

Bank syariah merupakan sebuah lembaga yang bertujuan mencari laba dari aktivitas keuangannya. Sehingga bank syariah akan selalu berusaha untuk memaksimalkan keuntungan. (Indonesia, 2014). Tetapi bank syariah juga mempunyai suatu tujuan dan amanat undang-undang yang harus dipenuhi yaitu untuk melakukan pembangunan nasional, 
dengan indikator ketercapaiannya yaitu pemerataan kesejahteraan rakyat. Tujuan ini tidak akan dicapai jika jenis pembiayaan berbasis equity masih rendah. Hal ini karena pembiayaan berbasis equity dimaksudkan untuk modal kerja. Dengan munculnya lapangan usaha baru akan menyerap tenaga kerja. Ketika bank syariah menyalurkan pembiayaan ke sektor produktif melalui pembiayaan berbasis equity maka akan membuka lapangan usaha dan menyerap tenaga kerja. Dengan demikian tujuan bank syariah untuk melakukan pembangunan nasional, meningkatkan pemerataan kesejahteraan rakyat akan tercapai. (Arifin, 2012)

Bank syariah harus mampu menyalurkan dananya pada sektor produktif yang tepat sehingga dapat meningkatkan pemerataan kesejahteraan rakyat Perkembangan rasio gini, yang menggambarkan tingkat kesenjangan distribusi pendapatan rakyat, dari tahun 2009 sampai tahun 2013 dapat dilihat pada table di bawah ini:

\section{Tabel 1}

Laba Bank Syariah dan Indeks Gini Indonesia Tahun 2009 - 2013

\begin{tabular}{|l|r|}
\hline Tahun & \multicolumn{1}{|c|}{ Indeks Gini } \\
\hline 2009 & 0,37 \\
\hline 2010 & 0,38 \\
\hline 2011 & 0,41 \\
\hline 2012 & 0,41 \\
\hline 2013 & 0,413 \\
\hline \multicolumn{2}{|c|}{ Sumber $:$ Statistik Perbankan } \\
\hline
\end{tabular}

Indonesia dan Badan Pusat Statistik (data diolah)

Dari table 1 di atas dapat dilihat bahwa rasio gini pada tahun 2009-2013 menunjukkan tren yang meningkat. Artinya kesenjangan pendapatan masyarakat semakin tinggi atau tingkat pemerataan kesejahteraan masyarakat semakin rendah. Hal ini menjadi menarik untuk diteliti, mengingat tujuan bank syariah adalah untuk meningkatkan pemerataan masyarakat. Tapi faktanya pada tahun 2009-2013 tingkat pemerataan masyarakat malah semakin rendah. Sehingga peneliti merasa tertarik untuk meneliti ketercapaian tujuan bank syariah tersebut melalui pembiayaan yang disalurkan oleh bank syariah. Hal 
ini dikarenakan kegiatan yang dapat dilakukan bank syariah untuk mendukung pemerataan kesejahteraan masyarakat salah satunya adalah melalui penyaluran pembiayaannya

\section{B. Rumusan Masalah}

Dari latar belakang masalah di atas, dapat dirumuskan rumusan masalah dalam penelitian ini, yaitu (1)Bagaimana pengaruh penyaluran pembiayaan bank syariah terhadap pemerataan kesejahteraan rakyat?(2)Apakah bank syariah telah mampu menjalankan tujuan yang terkandung dalam UU No 21 Tahun 2008?

\section{Tujuan Penelitian}

Tujuan penelitian ini adalah untuk (1)Untuk mengetahui bagaimana pengaruh penyaluran pembiayaan bank syariah terhadap pemerataan kesejahteraan rakyat;(2)Untuk mengetahui apakah bank syariah telah mencapai tujuan bank syariah yang terkandung dalam UU No 21 Tahun 2008.

\section{Metode Penelitian}

Metodologi penelitian yang digunakan dalam penelitian ini adalah metode penelitian menggunakan model regresi dengan metode kuadrat terkecil (Ordinary Least Squares $=$ OLS $)$. (Zuhroh, Ismail, \& Maskie, 2015) Metode penelitian model regresi dianggap relevan dengan kerangka pemikiran/kerangka teori yang menjelaskan tentang pengaruh variable independen (margin dan akses) terhadap variable dependen (permintaan pembiayaan mudharabah). Alat analisis yang digunakan dalam penelitian ini adalah Eviews versi 6. (Vogelvang, 2005)

Penelitian ini bertujuan untuk mengetahui ketercapaian tujuan bank syariah yang terkandung dalam UU No 21 Tahun 2008 dengan cara meneliti pengaruh penyaluran pembiayaan bank syariah terhadap pemerataan kesejahteraan masyarakat. Sehingga yang menjadi objek dalam penelitian ini adalah penyaluran pembiayaan bank syariah dan rasio gini.

Data yang digunakan dalam penelitian ini yaitu data yang 
bersumber dari Statistik Perbankan Syariah yang dikeluarkan oleh Bank Indonedia periode 2009 sampai 2013. Analisis data yang digunakan merupakan analisis data triwulan sehingga jumlah periode yang diteliti adalah sebanyak 20 periode.

\section{E. Kajian Pustaka}

\section{Tujuan Bank Syariah}

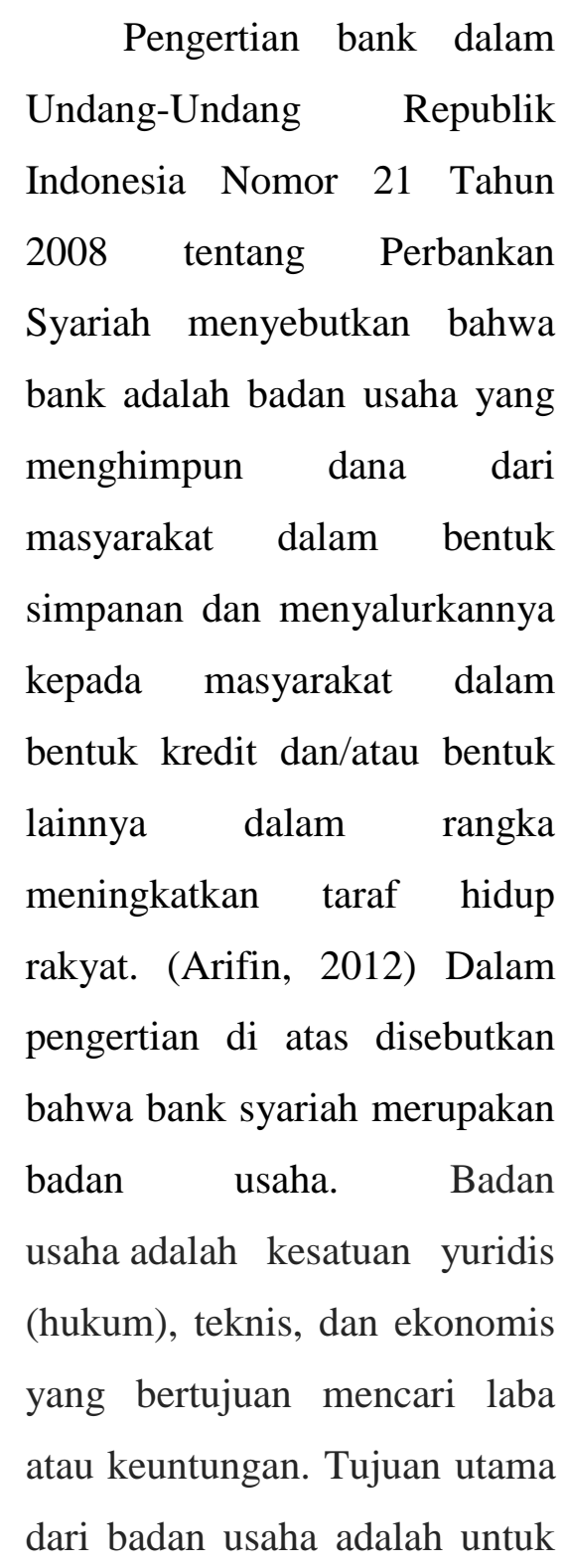

mencari laba. Hal ini berlaku untuk semua jenis badan usaha, baik Badan Usaha Milik Swasta maupun Badan Usaha Milik Negara. Undang-Undang Republik Indonesia Nomor 19 Tahun 2003 tentang BUMN menyebutkan bahwa tujuan didirikannya BUMN adalah: (Sipayung, Nasution, \& Siregar, 2013)

a. memberikan sumbangan bagi perkembangan perekonomian nasional pada umumnya dan penerimaan negara pada khususnya;

b. mengejar keuntungan;

c. menyelenggarakan kemanfaatan umum berupa penyediaan barang dan/atau jasa yang bermutu tinggi dan memadai bagi pemenuhan hajat hidup orang banyak;

d. menjadi perintis kegiatan-kegiatan usaha yang belum dapat dilaksanakan oleh sektor swasta dan koperasi; 
e. turut aktif memberikan

bimbingan dan bantuan

kepada pengusaha golongan ekonomi

lemah, koperasi, dan masyarakat.

Sebagai badan usaha, bank syariah juga bertujuan untuk mencari laba karena bank syariah pun merupakan badan usaha. Sedangkan sebagai sebuah bank, bank syariah memiliki tiga fungsi utama yaitu (Listanti, 2015) :

a. Agent of trust yaitu bank sebagai lembaga yang dipercaya masyarakat untuk dapat menitipkan dananya dan menyalurkannya pada sektor-sektor yang tepat.

b. Agent of development yaitu bank sebagai lembaga yang mendukung kegiatan investasi, distribusi, dan konsumsi barang dan jasa.

c. Agent of services yaitu bank sebagai lembaga yang memberikan jasa- jasa keuangan kepada masyarakat.

Dalam Undang-Undang RI Nomor 21 Tahun 2008 tentang Perbankan Syariah disebutkan bahwa perbankan syariah berujuan menunjang pelaksanaan pembangunan nasional dalam rangka meningkatkan keadilan, kebersamaan, dan pemerataan kesejahteraan rakyat. Tujuan bank syariah ini dapat tercapai jika bank syariah menyalurkan kreditnya pada sektor-sektor produktif yang dapat meningkatkan perekonomian secara riil. Dengan demikian maka akan ada sektor usaha baru dan bertambahnya lapangan kerja. Pada akhirnya hal ini akan menyebabkan pendapatan dan kesejahteraan rakyat akan meningkat. Tetapi ketika bank syariah lebiha banyak menyalurkan kreditnya pada sektor konsumtif maka pencapaian tujuan pembangunan nasional ini akan terhambat. Hal ini dikarenakan kredit yang disalurkan pada sektor konsumtif tidak akan membuka sektor usaha yang 
baru dan penambahan lapangan kerja secara langsung.

\section{Pembiayaan Bank Syariah}

Pembiayaan atau kredit menurut Bank Indonesia adalah penyediaan uang atau tagihan yang dapat dipersamakan dengan itu, berdasarkan persetujuan atau kesepakatan pinjam meminjam dengan pihak lain yang mewajibkan pihak peminjam untuk melunasi utangnya setelah jangka waktu tertentu dengan pemberian bunga (Indonesia B. , 2013). Sedangkan pembiayaan menurut kodifikasi perbankan syariah adalah penyediaan dana atau tagihan yang dipersamakan dengan itu, berupa: (1) Transaksi bagi hasil dalam bentuk Mudhârabah dan Musyârakah, (2) Transaksi sewa menyewa dalam bentuk ijarah atau sewa beli dalam bentuk ijarah muntahiya bittamlik, (3) Transaksi jual beli dalam bentuk piutang murabahah, salam, dan istishna,(4) Transaksi pinjam meminjam dalam bentuk piutang qardh, dan (5) Transaksi sewa menyewa jasa dalam bentuk ijarah dalam transaksi multijasa.
(Indonesia B. , Booklet Perbankan Indonesia, 2006)

Landasan hukum pertama bagi akad syariah pada perbankan di Indonesia adalah UndangUndang Nomor 7 Tahun 1992 tentang Perbankan. UndangUndang tersebut kemudian diperbaharui dengan dikeluarkannya Undang-Undang Nomor 10 Tahun 1998. UndangUndang yang mengatur secara khusus tentang perbankan syariah yaitu Undang-Undang Republik Indonesia Nomor 21 Tahun 2008 tentang Perbankan Syariah. Dasar hukum yang lain tentang perbankan syariah adalah dalam Peraturan Bank Indonesia nomor 7/46/PBI/2005 dan nomor 9/19/PBI/2007. Peraturan yang lain yang dapat dijadikan dasar hukum bagi perbankan syariah yaitu Surat Edaran Bank Indonesia nomor 10/14/DPbs/2008. Peraturanperaturan hukum tersebut kemudian dikuatkan dengan dikeluarkannya fatwa Dewan Syariah Nasional No.07//DSNMUI/IV/2000 tentang Pembiayaan Mudhârabah (qiradh). Peraturanperaturan di atas adalah dasar hukum yang kuat untuk perbankan 
syariah dan diterapkannya akad

Mudhârabah di dalamnya. (Fauzan, 2014)

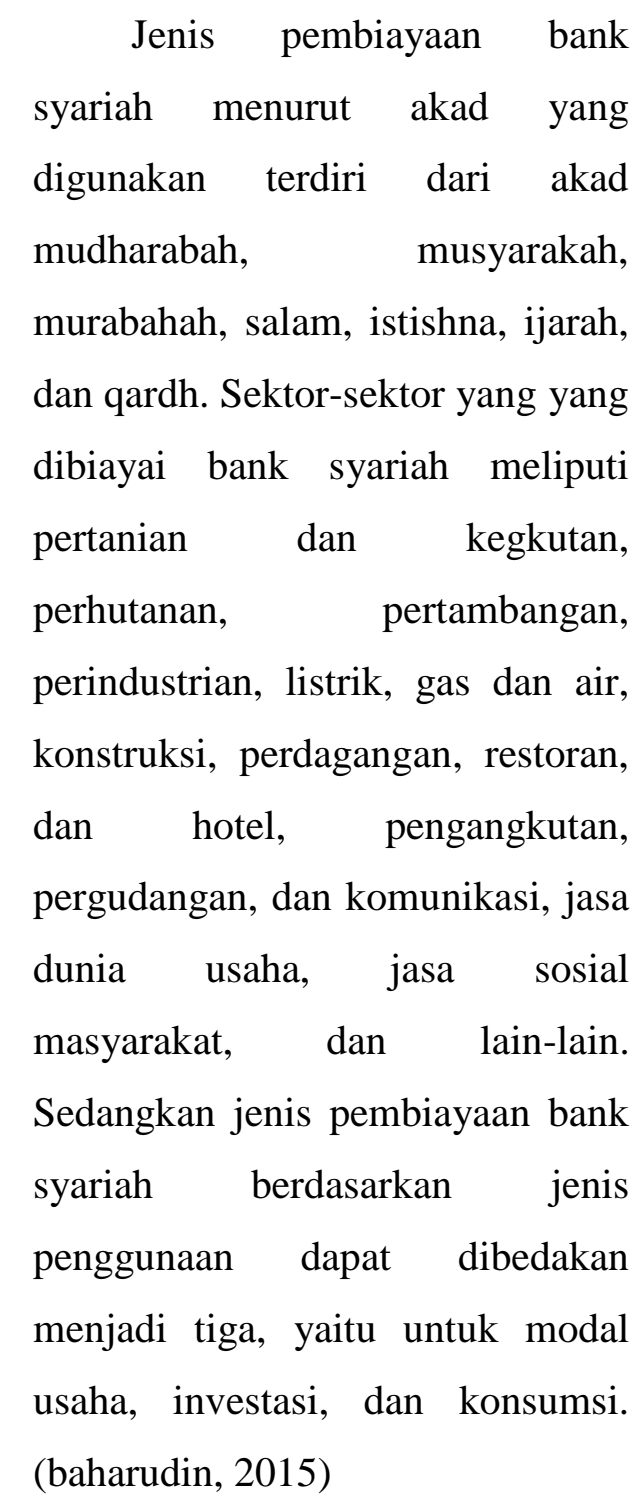

\section{PEMBAHASAN}

\section{A. Landasan Teori}

\section{Sejarah Bank Syariah di} Indonesia

$$
\begin{aligned}
& \text { Praktik perbankan telah } \\
& \text { dilaksanakan oleh umat Islam } \\
& \text { sejak zaman Rasulullah SAW. } \\
& \text { Umat Islam terbiasa menitipkan }
\end{aligned}
$$

harta, meminjamkan uang, dan melakukan pengiriman uang, baik antara sesama muslim ataupun dengan non muslim. Ketiga aktivitas tersebut merupakan fungsi perbankan yang utama yaitu menerima titipan uang, meminjamkan uang, dan memberikan jasa keuangan. Sehingga dapat dikatakan praktik perbankan telah menjadi kebutuhan umat Islam, bahkan sejak zaman Rasulullah SAW. (Karim, 2010)

Dasar-dasar pada akad perbankan syariah modern sebenarnya sudah ditentukan sejak zaman Rasulullah SAW. Namun terdapat beberapa penyesuaian dalam beberapa akad agar bisa diterapkan pada lembaga keuangan syariah modern. Hal ini merupakan kemajuan besar dalam bidang muamalah, dimana umat Islam dapat melaksanakan agamanya dengan sempurna, termasuk dalam bidang ekonomi. Adanya bank syariah dapat menghindarkan umat Islam dari bahaya riba yang menjadi pilar utama pada perbankan 
konvensional. (Iskandar \&

Nasir, 2014)

$\begin{array}{rrr}\text { Bank } & \text { syariah } & \text { yang } \\ \text { pertama } & \text { didirikan } & \text { adalah }\end{array}$

Islamic Rural Bank pada tahun

1963 di Mesir. Bank swasta pertama yang menerapkan prinsip syariah yaitu Dubai Islamic Bank yang didirikan oleh sekelompok usahawan muslim dari berbagai negara pada tahun 1975 di Dubai. Pada tahun 1977 berdiri dua bank Islam yaitu Faysal Islamic Bank di Mesir dan Sudan dan Kuwait Finance House di Kuwait.

Perkembangan bank syariah secara internasional diawali dengan diadakannya sidang menteri luar negeri yang diselenggarakan oleh Organisasi Konferensi Islam (OKI) pada tahun 1970 di Pakistan. Pertemuan tersebut menghasilkan usulan untuk mendirikan Islamic Development Bank (IDB) dan disetujui pada tahun 1975 melalui sidang menteri keuangan OKI. Setelah didirikannya IDB maka sejak tahun 1980 mulai didirikan bank syariah di berbagai negara seperti di Mesir, Sudan, negaranegara Teluk, Pakistan, Iran, Malaysia, Bangladesh, dan Turki. (Anshori, 2009)

Pendirian bank syariah di Indonesia baru dilakukan setelah disahkannya UndangUndang Nomor 7 tahun 1992 yang memuat ketentuanketentuan yang memperbolehkan pengelolaan bank berdasarkan prinsip bagi hasil yang kemudian dipertegas oleh Peraturan Pemerintah Nomor 72 Tahun 1992 tentang bank berdasar prinsip bagi hasil. Setelah disahkannya beberapa peraturan tentang bank syariah maka didirikan bank syariah pertama di Indonesia dengan nama Bank Muamalat Indonesia (BMI) pada tahun 1992. Sejak didirikannya BMI maka prinsip syariah mulai diterapkan pada dunia perbankan di Indonesia. Bank syariah di Indonesia terus mengalami perkembangan. Sampai tahun 2013 telah didirikan 11 Bank Umum Syariah (BUS), 23 Unit Usaha Syariah (UUS), dan 160 Bank Perkreditan Rakyat Syariah (BPRS). 


\section{Tujuan Bank Syariah}

\author{
Undang-Undang
}

RI

Nomor 21 Tahun 2008 tentang

Perbankan

Syariah

menyebutkan bahwa perbankan syariah berujuan menunjang pelaksanaan pembangunan nasional dalam rangka meningkatkan keadilan, kebersamaan, dan pemerataan kesejahteraan rakyat. Pemerataan kesejahteraan yang dimaksud diwakili oleh indeks gini. Indeks. Indeks gini merupakan suatu angka yang menggambarkan tingkat kesenjangan kesejahteraan masyarakat suatu negara. Semakin besar angka pada indeks gini maka semakin besar pula tingkat kesenjangan kesejahteraan masyarakat dan begitupula sebaliknya.

Pencapaian tujuan bank syariah merupakan representasi dari kebijakan yang diterapkan oleh bank syariah. Ada dua kemungkinan kebijakan yang diambil oleh bank syariah yaitu: (1) lebih memprioritaskan maksimalisasi pendapatan dan laba

(2) sama-sama memprioritaskan

baik maksimalisasi pendapatan dan laba maupun pemerataan kesejahteraan rakyat.

Berikut data total penyaluran pembiayaan bank syariah di Indonesia periode $2009-2013$ :

Tabel 2

Total Penyaluran Pembiayaan Bank Syariah (dalam milyar rupiah)

\begin{tabular}{|c|r|}
\hline Periode & \multicolumn{1}{|c|}{ Total Pembiayaan } \\
\hline 2009 & 46.886 \\
\hline 2010 & 68.181 \\
\hline 2011 & 102.655 \\
\hline 2012 & 147.505 \\
\hline 2013 & 184.122 \\
\hline
\end{tabular}

diolah)

Cara yang dapat dilakukan bank syariah untuk mencapai tujuannya, yaitu meningkatkan pemertaan kesejahteraan rakyat yaitu melalui kebijakannya dalam menyalurakn pembiayaannya. Hal ini mengingat bank syariah merupakan agen of distribution yang menjadi lembaga intermediasi keuangan dari surplus unit pada deficit unit. Selain itu, bank syariah sebagai agen of development yang mampu menyalurkan pembiayaannya pada sector riil dan sektor-sektor produktif yang dapat meningkatkan perekonomian rakyat, 
sehingga pemerataan kesejahteraan rakyat akan semakin tinggi.

Penyaluran pembiayaan bank syariah berdasarkan penggunaannya dapat dikelompokkan menjadi 3, yaitu untuk keperluan modal kerja, investasi, dan konsumsi. Berikut data total penyaluran pembiayaan bank syariah di Indonesia periode 2009 - 2013 berdasarkan jenis penggunaannya:

Berikut data total
penyaluran pembiayaan bank
syariah di Indonesia periode
$2009-2013$ :

Tabel 3

Total Penyaluran Pembiayaan Bank Syariah

Berdasarkan Jenis Penggunaannya (dalam milyar rupiah)

\begin{tabular}{|c|c|c|c|}
\hline Periode & Modal Kerja & Investasi & Konsumsi \\
\hline 2009 & 22,873 & 9,955 & 14,058 \\
\hline 2010 & 31,855 & 13,416 & 22,910 \\
\hline 2011 & 41,698 & 17,903 & 43,053 \\
\hline 2012 & 56,097 & 26,585 & 64,823 \\
\hline 2013 & 67,682 & 32,297 & 77,340 \\
\hline \multicolumn{3}{|c|}{ Sumber : Statistik Perbankan Syariah (data diolah) }
\end{tabular}

Dari table 3 di atas dapat dilihat bahwa penyaluran pembiayaan untuk modal kerja paling banyak pada tahun 2009 dan 2010. Sedangkan pada tahun 2011, 2012, dan 2013 penyaluran pembiayaan untuk konsumsilah yang paling besar. Proporsi pembiayaan untuk investasi tetap yang paling kecil mulai tahun 2009 sampai 2013.



Adapun penyaluran pembiayaan bank syariah periode 2009-2013 berdasarkan akad yang dipakai adalah sebagai berikut: 
Tabel 4

Total Penyaluran Pembiayaan Bank Syariah

Berdasarkan Jenis Penggunaannya

(dalam milyar rupiah)

\begin{tabular}{|r|l|c|c|c|c|c|}
\hline No & Akad & $\mathbf{2 0 0 9}$ & $\mathbf{2 0 1 0}$ & $\mathbf{2 0 1 1}$ & $\mathbf{2 0 1 2}$ & $\mathbf{2 0 1 3}$ \\
\hline 1 & Mudhârabah & 6.597 & 8.631 & 10.229 & 12.023 & 13.664 \\
\hline 2 & Musyârakah & 10.412 & 14.624 & 18.960 & 27.667 & 37.921 \\
\hline 3 & Murâbahah & 26.321 & 37.508 & 56.365 & 88.004 & 107.484 \\
\hline 4 & Lainnya & 3.557 & 7.418 & 17.102 & 19.811 & 20.214 \\
\hline \multicolumn{5}{|c|}{ Sumber : Statistik Perbankan Syariah (data diolah) } \\
\hline
\end{tabular}

menggambarkan tingkat

Dari table 4 di atas dapat

dilihat bahwa pembiayaan dengan akad murabahah atau yang berbasis jual beli merupakan pembiayaan yang paling banyak dan berada di kisaran $60 \%$. Sedangkan $40 \%$ sisanya terdiri dari pembiayaan mudharabah, musyarakah, salam, istishna, ijarah, dan qardh.

\section{B. Hasil Penelitian dan Analisis} Data

Indikator yang dipakai untuk mewakili pemerataan kesejahteraan masyarakat dalam penelitian ini adalah dengan menggunakan rasio gini. Rasio gini merupakan suatu angka yang kesenjangan kesejahteraan

masyarakat suatu negara.Artinya jika rasio gini kecil atau mendekati nol, maka tingkat pemerataan kesejahteraan masyarakat tinggi. Sebaliknya jika rasio gini besar atau mend ekati 1 , maka tingkat pemerataan kesejahteraan masyarakat rendah.

Pada penelitian ini rasio gini memiliki notasi statistik yaitu Y. Penyaluran pembiayaan bank syariah diduga akan mempengaruhi rasio gini. Berikut hasil pengujian statistik yang menguji pengaruh penyaluran pembiayaan bank syariah terhadap rasio gini: 
Tabel 5

Pengaruh Penyaluran Pembiayaan Bank Syariah terhadap Pemerataan Kesejahteraan Masyarakat

\begin{tabular}{crrrr}
\hline \hline Variable & Coefficient & Std. Error & t-Statistic & Prob. \\
\hline \hline C & 0.366204 & 0.005332 & 68.67464 & 0.0000 \\
$\mathrm{~K}$ & $3.10 \mathrm{E}-07$ & $4.89 \mathrm{E}-08$ & 6.350303 & 0.0000 \\
\hline \hline R-squared & & & & 40.32635 \\
Adjusted R-squared & 0.691392 & F-statistic & & 0.000006 \\
\hline \hline
\end{tabular}

(Sumber: Hasil Perhitungan Regresi Eviews 6)

Tabel 2 di atas menunjukkan bahwa nilai $\mathrm{t}$ hitungnya sebesar 6.350303, sedangkan nilai $\mathrm{t}$ tabel dengan df sebesar 18 adalah 2,101. Nilai t hitung lebih besar dari $\mathrm{t}$ tabel sehingga $\mathrm{H}_{0}$ ditolak dan $\mathrm{H}_{1}$ diterima. Pengujian dengan uji $\mathrm{t}$ menunjukkan bahwa penyaluran pembiayaan bank syariah berpengaruh secara signifikan terhadap indeks gini.

Nilai F hitung dari hasil pengujian di atas adalah sebesar 40.32635, sedangkan nilai $F$ tabelnya adalah sebesar 4,41. Nilai $F$ tabel didapat dari pertemuan antara df N1 sebesar 1 dan df N2 sebesar 18 pada derajat kepercayaan 95\%. Nilai $\mathrm{F}$ hitung lebih besar dari $\mathrm{F}$ tabelnya sehingga $\mathrm{H}_{0}$ ditolak dan $\mathrm{H}_{1}$ diterima. Pengujian dengan uji $\mathrm{F}$ juga menunjukkan bahwa penyaluran pembiayaan bank syariah berpengaruh secara signifikan terhadap indeks gini.

Data di atas menunjukkan bahwa nilai $\mathrm{t}$ hitung dan $\mathrm{F}$ hitung lebih besar dari nilai $\mathrm{t}$ tabel dan $\mathrm{F}$ tabel. Nilai probabilitasnya juga sebesar 0,00000. Ini berarti $\mathrm{H}_{0}$ yang menyatakan tidak ada pengaruh yang signifikan antara penyaluran pembiayaan bank syariah terhadap indeks gini.

Nilai $R$ squared nya adalah sebesar 0.691392 dan nilai Adjusted $\mathrm{R}$ squared nya adalah sebesar 0.674247. Ini berarti rasio gini dipengaruhi oleh penyaluran pembiayaan bank syariah sebesar 
$67,4247 \%$. Sisanya sebesar

$32,5753 \%$ dipengaruhi oleh

faktor lain di luar penelitian.

Persamaan yang didapat dari

hasil pengujian di atas yaitu:

\section{$\mathrm{Y}=3.10 \mathrm{E}-07+$ \\ $0.366204 X$}

Keterangan:

$\mathrm{X}$ : Penyaluran

Pembiayaan Bank SYariah

Y : Tingkat Kesenjangan

Pemerataan Kesejahteraan

Rakyat (Rasio Gini)

Dari persamaan di atas bisa dilihat bahwa penyaluran pembiayaan bank syariah berpengaruh positif terhadap rasio gini. Setiap penambahan 1 satuan $\mathrm{X}$ akan menambah 0.366204 nilai Y. Hasil pengujian ini tidak sesuai dengan hipotesis. Ini menunjukkan bahwa penyaluran pembiayaan bank syariah belum mampu mencapai tujuan meningkatkan pemerataan kesejahteraan masyarakat. Bahkan penyaluran pembiayaan bank syariah malah mempertinggi kesenjangan pendapatan rakyat.

Seharusnya penyaluran pembiayaan bank syariah berpengaruh negative terhadap rasio gini yang berarti kebijakan penyaluran pembiayaan bank syariah mendorong peningkatan pemerataan kesejahteraan rakyat.

Hal ini dikarenakan ada asumsi yang tidak terpenuhi. Penyaluran pembiayaan bank syariah dapat menurunkan rasio gini dengan asumsi pembiayaan tersebut digunakan untuk modal kerja atau perluasan usaha. Dengan demikian dapat menambah lapangan kerja dan meningkatkan pendapatan masyarakat. Jika dilihat prosentase penyaluran pembiayaan bank syariah di Indonesia pada tahun 2009 sampai 2013 maka penyaluran pembiayaan didominasi oleh pembiayaan berbasis jual beli. Pembiayaan jenis ini digunakan untuk keperluan konsumtif. Berikut prosentase penyaluran pembiayaan bank syariah pada tahun 2009 sampai 2013: 
Tabel 6

Prosentase Penyaluran Pembiayaan Bank Syariah

\begin{tabular}{|l|r|r|r|r|}
\hline Tahun & Mudhârabah & Musyarakah & Murabahah & Lainnya \\
\hline 2009 & $14,07 \%$ & $22,21 \%$ & $56,14 \%$ & $7,59 \%$ \\
\hline 2010 & $12,66 \%$ & $21,45 \%$ & $55,01 \%$ & $10,88 \%$ \\
\hline 2011 & $9,96 \%$ & $18,47 \%$ & $54,91 \%$ & $16,66 \%$ \\
\hline 2012 & $8,15 \%$ & $18,76 \%$ & $59,66 \%$ & $13,43 \%$ \\
\hline 2013 & $7,62 \%$ & $21,15 \%$ & $59,95 \%$ & $11,27 \%$ \\
\hline
\end{tabular}

Sumber : Statistik Perbankan Indonesia (data diolah)

Data di atas menunjukkan bahwa penyaluran pembiayaan bank syariah didominasi oleh jenis pembiayaan murabahah. Jika diambil rata-rata penyaluran pembiayaan tahun 2009 sampai 2013, maka pembiayaan mudhârabah sebesar 10,49\%, pembiayaan musyarakah sebesar $20,41 \%$, pembiayaan murabahah sebesar $57,13 \%$, dan pembiayaan lainnya sebesar $11,97 \%$. Jenis pembiayaan yang ditujukan untuk sektor usaha adalah jenis pembiayaan mudhârabah dan musyarakah dengan rata-rata pembiayaan sebesar $30,90 \%$. Sisanya sebesar $69,70 \%$ disalurkan pada sektor selain sektor usaha, seperti sektor konsumsi.

$$
\text { Pembiayaan }
$$
ditujukan untuk sektor konsumsi tidak akan menambah lapangan usaha dan meningkatkan pendapatan masyarakat. Pembiayaan jenis ini bahkan akan mengurangi pendapatan masyarakat karena mereka harus membayar margin sebagai kompensasi dari pembiayaan tersebut. Keadaan ini akan membuat tingkat kesenjangan

\section{SIMPULAN}

Rasio gini dipengaruhi oleh penyaluran pembiayaan bank syariah sebesar $67,4247 \%$. Sisanya sebesar $32,5753 \%$ dipengaruhi oleh faktor lain di luar penelitian. Persamaan yang didapat dari hasil pengujian di atas yaitu $\mathrm{Y}=3.10 \mathrm{E}-$ $07+0.366204$ X. Dari persamaan di atas bisa dilihat bahwa 


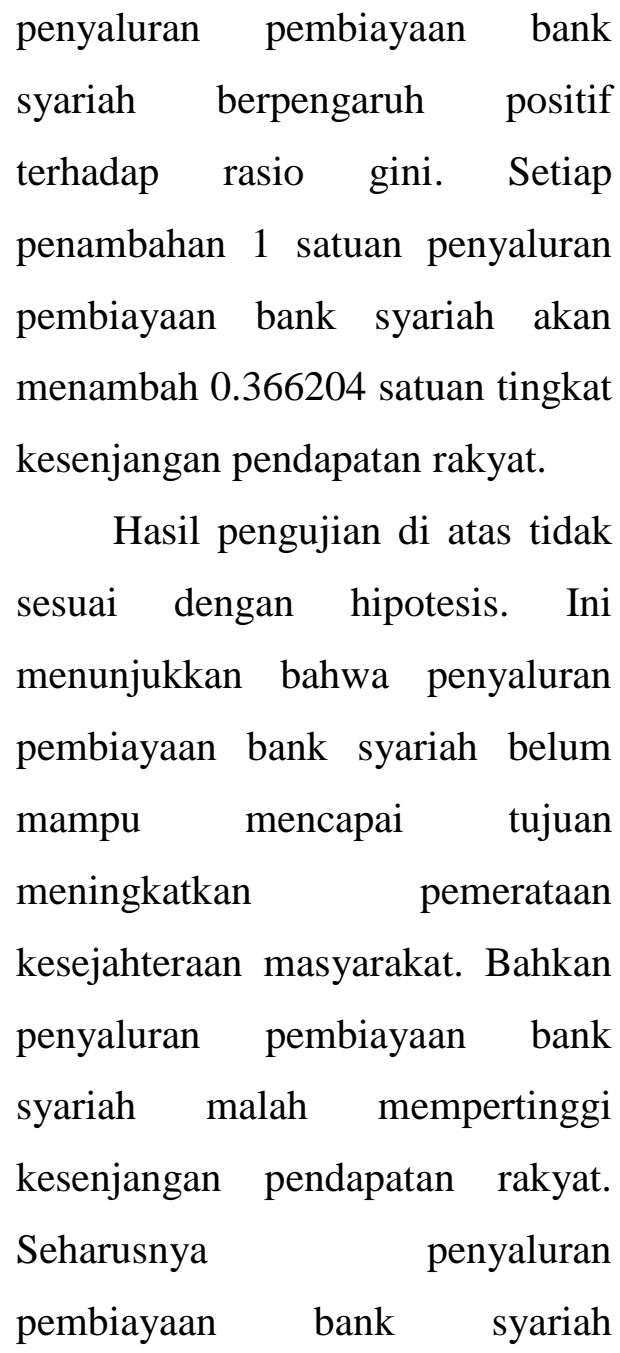

\section{DAFTAR PUSTAKA}

Anshori, A. G. (2009). Perbankan Syariah di Indonesia. Yogyakarta: Gadjah Mada University Press.

Arifianto, W. (2013). "Pengaruh Pertumbuhan Ekonomi Terhadap Distribusi Pendapatan di Indonesia. Jurnal Pendidikan Ekonomi (JUPE) 1.3 .

Arifin, Z. (2012). Dasar-dasar manajemen bank syariah. Pustaka Alvabet.

baharudin, A. (2015). Utang dan Pendapatan Perusahaan dalam Kriteria dan Penerbitan Efek Syariah Perspektif Hukum Bisnis Syariah. berpengaruh negative terhadap rasio gini yang berarti kebijakan penyaluran pembiayaan bank syariah mendorong peningkatan pemerataan kesejahteraan rakyat.

Bank Indonesia perlu menghimbau atau memberikan anjuran pada Bank Syariah untuk melakukan realokasi penyaluran pembiayaan pada bank syariah. Jenis pembiayaan untuk tujuan modal usaha perlu ditambah supaya dapat menggerakkan sektor riil, menambah lapangan kerja, dan meningkatkan pendapatan masyarakat. Dengan demikian pemerataan kesejahteraan masyarakat dapat ditingkatkan.

Yogyakarta: Universitas islam Sunan Kalijaga.

Eka, P. Y., Amar, S., \& Aimon, H. (2015). Analisis Faktor-Faktor Yang Mempengaruhi Pertumbuhan Ekonomi Dan Ketimpangan Pendapatan Di Indonesia. Jurnal Kajian Ekonomi 3.6.

Fauzan. (2014). Implementasi Shariah Governance di Bank Syari'ah. Jurnal Ilmu Syari'ah dan Hukum Vol 49.1.

Indonesia, B. (2006). Booklet Perbankan Indonesia. Jakarta: Diraktorat Perijinan dan Informasi Perbankan.

Indonesia, B. (2013). "Statistik ekonomi dan keuangan Indonesia. jakarta: Bank Indonesia. 
Indonesia, I. B. (2014). Memahami Bisnis Bank Syariah. Gramedia Pustaka Utama.

Iskandar, M. N., \& Nasir, M. (2014). Pengaruh Kinerja Keuangan Terhadap Tingkat Bagi Hasil Deposito Mudharabah Dan Tingkat Pengembalian Ekuitas Pada Bank Umum Syariah Di Indonesia. Fakultas ekonomi dan bisnis.

Karim, A. (2010). "Bank Islam: Analisis Fiqh dan Keuangan (Edisi Keempat). Jakarta: raja Grapindo Persada.

Listanti, D. (2015). UPAYA PENANGANAN PEMBIAYAAN MURABAHAH BERMASALAH PADA LEMBAGA KEUANGAN SYARIAH (Studi Pada KJKS Baitul Maal Wat Tamwil (BMT) Mandiri Sejahtera Karangcangkring Gresik Jawa timur Periode 20112013). Jurnal Administrasi Bisnis 18.1.

Radhi, F. (2008). Kebijakan ekonomi pro rakyat. Republika.

Rustariyuni, S. D. (2014). Pengaruh Gini Ratio, Pengeluaran Non Makanan Per Kapita, Belanja Daerah dan Laju Pertumbuhan Ekonomi pada Indeks Pembangunan Manusia Kabupaten/Kota di Provinsi Bali Periode 2004-2012. PIRAMIDA 10.1.

Saleh, S. (2002). "Faktor-faktor penentu tingkat kemiskinan regional di Indonesia. Economic Journal of Emerging Markets 7.2.

Sipayung, J., Nasution, B., \& Siregar, M. (2013). Tinjauan yuridis holdingisasi BUMN dalam rangka peningkatan kinerja menurut perspektif hukum perusahaan. " TRANSPARENCY 1.1.
Vogelvang, B. (2005). Econometrics: theory and applications with Eviews. Pearson Education.

Zuhroh, I., Ismail, M., \& Maskie, G. (2015). Cost Efficiency of Islamic Banks in Indonesia-A Stochastic Frontier Analysis. Procedia-Social and Behavioral Sciences 211, 1122-1131. 